\title{
Perjuangan K. H. Munir Hasyim Latief di Laskar Hizbullah dalam Perang Mempertahankan Kemerdekaan di Jawa Timur 1945-1953 M
}

\author{
Miftahul Khoiri \\ UIN Sunan Kalijaga Yogyakarta \\ Jl. Laksda Adisucipto, Papringan, Caturtunggal, Kec. Depok, Yogyakarta \\ techochoir@gmail.com
}

\begin{abstract}
K. H. Munir Hasyim Latief's struggle at Laskar Hizbullah in the War Maintaining Independence in East Java 1945-1953 CE. This article discusses the biography and struggle of K. H. Munir Hasyim Latief in Laskar Hizbullah in the war to defend independence in East Java. In historical records, Laskar Hizbullah is an association of santri youth in Islamic boarding schools throughout Indonesia. The Hizbullah Warriors were formed as a reserve for Japanese soldiers used to fight against allies. In this case, K. H. M. Hasyim Latief as a local figure who had participated in the Laskar Hizbullah training in Bogor Cibarusa held by the Japanese. After returning from the training, $\mathrm{K}$. H. M. Hasyim Latief was asked to train the santri in Jombang to prepare the troops as an antipation of the Dutch who would come to Indonesia again. This article focuses on three things, namely the biography of K. H. M. Hasyim Latief. Struggle K. H. M. Hasyim Latief in Laskar Hizbullah in the war to defend independence. And the reason for the participation of K. H. M. Hasyim Latief in the Laskar Hizbullah to maintain independence. This research shows that, K. H. M. Hasyim Latief was born in Sumobito, Jombang, East Java, who lives in the Tebuireng Jombang boarding school which is directly cared for by K. H. Hasyim Asy'ari. in his struggle in the Hezbollah army, he became a coach, then became a commander when the situation fought to the Sidoarjo area, Surabaya. His participation was also encouraged by the clerics, especially K. H. Hasyim Asyari. And also for his own encouragement, because he is indeed a descendant of fighters through his grandfather. Also because his father had been imprisoned by the Dutch.
\end{abstract}

Keywords: Struggle, Biography K. H. Munir Hasyim Latief, Laskar Hizbullah, Independence.

Abstrak: Perjuangan K. H. Munir Hasyim Latief di Laskar Hizbullah dalam Perang Mempertahankan Kemerdekaan di Jawa Timur 1945-1953 M. Artikel ini membahas tentang biografi dan perjuangan K.H. Munir Hasyim Latief di Laskar Hizbullah dalam perang mempertahankan kemerdekaan di Jawa Timur. Dalam catatan historis, Laskar Hizbullah adalah perkumpulan para pemuda santri di pesantren seluruh Indonesia. Laskar Hizbullah dibentuk sebagai cadangan tentara Jepang yang digunakan untuk berperang melawan sekutu. Dalam hal ini, K. H. M. Hasyim Latief sebagai tokoh lokal yang pernah mengikuti latihan Laskar Hizbullah di Cibarusa Bogor yang diadakan oleh pihak Jepang. Setelah pulang dari latihan tersebut, K. H. M. Hasyim Latief diminta untuk melatih para santri di Jombang untuk mempersiapkan pasukan sebagai antipasi pihak Belanda yang akan datang ke Indonesia kembali. Artikel ini memfokuskan kepada tiga hal, yakni biografi K. H. M. Hasyim Latief. Perjuangan K. H. M. Hasyim Latief di Laskar Hizbullah dalam perang mempertahankan kemerdekaan. Dan alasan keikut sertaan K. H. M. Hasyim Latief dalam Laskar Hizbullah untuk mempertahankan kemerdekaan. Penelitian ini menunjukkan bahwa, K. H. M. Hasyim Latief lahir di Sumobito, Jombang, Jawa Timur, yang mondok di pesantren Tebuireng Jombang yang diasuh langsung oleh K. H. Hasyim Asy'ari. dalam perjuangannya di laskar hizbullah, beliau menjadi pelatih, kemudian menjadi komandan ketika situasi pertempuran ke wilayah Sidoarjo, Surabaya. Keikut sertaannya beliau juga didorong oleh para kiai, terutama K. H. Hasyim Asyari. Dan juga atas dorongan dirinya sendiri, karena memang beliau keturunan dari pejuang lewat kakeknya. Juga karena ayahnya sempat dipenjarah oleh pihak Belanda.

Kata Kunci: Perjuangan, Biografi K. H. Munir Hasyim Latief, Laskar Hizbullah, Kemerdekaan. 


\section{Pendahuluan}

Pada tanggal 2 November, Soekarno memerintahkan genjatan senjata atas permintaan Inggris, tetapi pada akhir bulan November, pertempuran telah berkobar lagi dan pihak Inggris mundur ke daerah pesisir. Surabaya menjadi ajang pertempuran yang paling hebat selama revolusi, sehingga menjadi lambang perlawanan nasional. Ketika seorang kapten angkatan laut belanda tiba di Surabaya sebagai wakil sekutu yang pertama. Shibata menyerah kepadanya pada tanggal 3 Oktober dan sesudah itu, dengan mengakui kenyataan akan kekuasaan bangsa Indonesia atas kota tersebut, memerintahkan pasukannya supaya menyerahkan senjata mereka yang tersisa kepada rakyat Indonesia yang akan bertanggung jawab atas penyerahan senjata-senjata itu kepada pihak sekutu. Pada akhir bulan Oktober dan awal bulan November, para pemimpin Nahdlatul Ulama dan Masyumi menyatakan bahwa perang mempertahankan tanah air Indonesia adalah perang sabil, suatu kewajiban atas semua muslim. Para Kiai dan Santri-santri mereka mulai mengalir dari PesantrenPesantren di Jawa Timur ke Surabaya.

Terlepas dari semua itu, sejarah tidak akan lepas dari peran seorang tokoh, tokoh dalam sejarah berperan aktif sebagai penghidup sebuah peristiwa sejarah. setiap zaman selalu muncul seorang tokoh. diantara mereka ada yang menjadi serupa mutiara karena idealisme, integritas yang menawan dan pengorbanan yang luar biasa. Tujuan mereka sama, yaitu mewujudkan Indonesia sebagai bangsa yang berdaulat dan merdeka. Tidak akan ada sejarah jika tidak ada tokoh yang berperan didalamnya. Kemudian, sebagai orang yang jauh dari kehidupan tokoh-tokoh tersebut. maka tugas kita sekarang adalah menulisnya, dan memperkenalkan mutiara tersebut.
Jombang pada saat itu menjadi bagian dari karesidenan Surabaya yang turut andil dalam perang mempertahankan kemerdekaan. Salah satu tokoh yang pernah ikut dalam latihan kemiliteran laskar hizbullah yang diadakan Jepang adalah Hasyim Latief. yang mana ketika itu, Jepang membutuhkna tentara untuk pasukan tempur melawan sekutu, sehingga Jepang ketika menduduki Indonesia melatih para pemuda Indonesia, Khususnya pemuda Islam (santri) yang ada di pesantrenpesantren. Sehingga lewat K. H. Wachid Hasyim menyuruh tiap-tiap kota mengirimkan perwakilan untuk dilatih kemiliteran.

Hasyim Latirf adalah seorang anak muda yang berasal dari Sumobito Jombang, yang masih ada keturunan darah pejuang dari kakeknya. Yang waktu itu mondok di pesantren Tebuireng yang mendiami pesantren Seblak, yang berada di sebelah utara Pesantren Tebuireng.

Artikel ini membahas tiga hal yang menjadi fokus permasalahannya, yaitu Bagaimana riwayat hidup Hasyim Latief. Bagaimana perjuangan Hasyim Latief di dalam Laskar Hizbullah. Mengapa Hasyim Latief memilih terlibat di dalam Laskar Hizbullah.

Dalam artikel ini mengunakan pendekatan biografi, dan pendekatan psikologi. Pendekatan biografi bertujuan untuk mengetahui riwayat hidup dari K. H. M. Hasyim Latief. Biografi atau catatan tentang hidup seseorang tersebut, meskipun sangat mikro, menjadi bagian dalam mosaik sejarah yang lebih besar. Malah, ada pendapat bahwa sejarah adalah penjumlahan dari biografi. Memang, dengan biografi dapat dipahami para pelaku sejarah, zaman yang menjadi latar belakang biografi, dan lingkungan sosial politiknya.

Sedangkan pendekatan psikilogis, dibuat 
untuk menganalisis K. H. M. Hasyim Latief yang melibatkan diri menjadi aktor di laskar hizbullah dalam mengikuti perang kemerdekaan tersebut. Dalam cerita sejarah aktor senantiasa mendapat sorotan yang kuat, baik sebagai individu maupun sebagai partisipan dalam kelompok. Aktor dalam kelompok menunjukkan kelakuan, suatu gejala yang menjadi objek khusus studi psikologi sosial. Dalam pelbagai peristiwa sejarah kelakuan kolektif sangat mencolok, antara lain sewaktu ada huru-hara, masa mengamuk, gerakan sosial atau gerakan protes atau gerakan revolusioner, yang kesemuannya menuntut penjelasan berdasarkan motivasi, sikap, dan tindakan kolektif.

Artikel ini termasuk penelitian sejarah, Yang mana dalam menelitian sejarah tersebut mempunyai metode dalam melakukan penelitian. Metode penelitian sejarah menurut Kuntowijoyo mempunyai lima tahap, yaitu: pemilihan topik, pengumpulan sumber, verifikasi (kritik sumber), interpretasi (analisis dan sintesis), dan historiografi (penulisan).

\section{Pembahasan}

\section{A. Biografi Munir Hasyim Latief}

Munir Hasyim Latief lahir di Sumobito, Jombang, Jawa Timur, pada tanggal 17 Mei 1928 M. Ayahnya bernama H. Abdul Latief. Kakeknya H. Imam Zuhdi, adalah seorang penghulu Agama di Sumobito, Jombang. Seperti anak-anak lainnya, dan hampir semua bangsa Indonesia yang hidup pada masa penjajahan, Hasyim Latief harus menjalani kehidupan yang serba sulit. Bahkan, ia pernah mengalami guncangan batin karena ibu dan kakaknya meninggal dunia. Sedangkan ayahnya berada dalam tahanan Jepang.

Ketika masa kecilnya Hasyim Latief tidak pernah mengenyam pendidikan formal. Baru Ketika beliau berusia 8 tahun, beliau belajar di Pondok Pesantren Tebuireng. Pada waktu itu pendidikan dikalangan umat Islam, khususnya di lingkungan Nahdlatul Ulama, belum menggunakan sistem Madrasah atau klasikal. Sistem pendidikan baru diterapkan sekitar 10 tahun kemudian. Jadi dalam pengajarannya, murid belum dipisahkan secara umur maupun ilmu pengetahuan.

Ketika di Tebuireng, Hasyim Latief menempati sebuah bilik bersama kakaknya dan 3 santri lain yang sama-sama berasal dari kecamatan Sumobito. Beliau (Hasyim Latief) menempati pesantren Seblak, yaitu salah satu bagian dari Pondok Pesantren Tebuireng, yang terletak di sebelah Utara Tebuireng. Pengasuhnya adalah K. H. Mahfudz Anwar yang dikenal sebagai ahli falak NU. Selama belajar di Pondok Pesantren Tebuireng beliau (Hasyim Latief) juga pernah menjadi Lurah Pondok. Disaat berdiri pandu Madrasah di Tebuireng dengan Abdul Muchith Muzadi sebagai ketua, dan Hasyim Latief sebagai sekretarisnya.

Ketika belajar di Pondok Pesantren Tebuireng, di samping diajar oleh K. H. Mahfudz Anwar, Hasyim Latief juga melakukan pembelajaran dengan cara otodidak, yaitu beliau (Hasyim Latif) memiliki kegemaran membaca buku-buku. Bagi seorang santri yang masih belia, membaca buku merupakan kebiasaan yang aneh. Beliau (Hasyim Latif) mendapatkan buku bacaan dengan cara menyewa di habilitek, yaitu Perpustakaan milik Pemerintah Belanda yang terdapat di Kecamatan-Kecamatan yang wilayahnya tergolong luas. Hasyim Latief bisa membaca buku berhuruf latin karena sang ayah telah mengenalkan huruf latin sejak sebelum beliau masuk Pondok Pesantren. Pada zaman Belanda tulisan latin itu disebut dengan tulisan gedrik. Mungkin hal itu diambil dari istilah bahasa 
Belanda yakni gedrek, yang artinya huruf cetak.

Setelah berakhirnya kekuasaan Belanda atas Bangsa Indonesia. Maka lahirlah masa kekuasaan baru yakni, masa kekuasaan Bangsa Jepang selama tiga setengah tahun, merupakan salah satu periode yang paling menentukan dalam sejarah Indonesia. Sebelum serbuan Jepang, tidak ada satu pun tantangan yang serius terhadap kekuasaan Belanda di Indonesia. Baru pada waktu Jepang menyerah, telah berlangsung begitu banyak perubahan luar biasa yang memungkinkan terjadinya Revolusi Indonesia. Jepang memberi sumbangan langsung pada perkembangan-perkembangan tersebut. terutama di Jawa, mereka (Belanda) mengindoktrinasi, melatih, dan mempersenjatai banyak generasi pemuda, terutama pemuda-pemuda Islam yang berada di Pesantren-pesantren.

Pada tanggal 3 Oktober 1943, Jepang membuat surat keputusan Osamu Seirei No. 44 yang dikeluarkan oleh Letjen Kumakichi Harada, Panglima Tentara ke-16 Jepang di pulau Jawa. Yaitu tentang pembentukan Kyodo Boei Giyugun atau pasukan sukarela pembela tanah air (PETA). Meskipun namanya kemudian berubah menjadi pembela tanah air. Ribuan pemuda, baik itu dari kalangan pemuda umum maupun kalangan pemuda Islam (Pesantren), madrasah dan kepanduan, semuanya berbondong-bondong mendaftar menjadi anggota PETA.

Setelah kuota terpenuhi, sedangkan masih banyak pemuda yang masih ingin bergabung mendaftar sebagai anggota PETA, terutama pemuda Islam dari kalangan Pesantren (Santri). Maka pada tanggal 15 Desember 1994, Jepang membentuk kaikyo Sainen teishintai alias Laskar Hizbullah (Tentara Allah) atas usulan dari K. H. A. Wahib Hasyim selaku pemimpin atau ketua dari Masyumi
(Majelis Syuro Muslimin Indonesia). Dari sinilah seluruh daerah diseluruh Jawa-Madura mengirim perwakilan dari masing-masing pemuda Islam (Santri) untuk menjadi anggota Laskar Hizbullah yang kemudian diberi pelatihan oleh tentara Jepang yang bertempat di daerah Cibarusa Bogor. Jombang yang menjadi karesidenan dari Surabaya, Lewat Pondok Pesantren Seblak Jombang, yang diasuh oleh K. H. Machfud Anwar, mengutus empat orang untuk mengikuti pelatihan Laskar Hizbullah di Cibarusa Bogor, untuk memenuhi permintaan markas tertinggi Hizbullah di Jakarta. keempat orang Santri tersebut yang di kirim ke Cibarusa adalah Hasyim Latief, Sa'dullah, Moh. Noer, dan Ma'sum.

Hasyim Latief wafat pada Bulan Mei 2005 dalam usia 77 tahun. Dimakamkan disamping Masjid Nurul Islam yang berada di dalam komplek YPM (Yayasan Pendidikan Ma'arif) Sepanjang, Taman, Sidoarjo Jawa Timur.

\section{B. Perjuangan Munir Hasyim Latief di dalam laskar Hizbullah}

Pada tanggal 8 Desember 1941, Jepang menyerang Wilayah Pearl Harbor, Hongkong, Filipina dan Malaysia. Negari Belanda segera mengikuti jejak sekutu-sekutunya dengan menyatakan perang terhadap Jepang. Pada tanggal 10 Januari 1942, penyerbuan Jepang ke Indonesia dimulai. Pada tanggal 15 Februari, pangkalan Inggris di Singapura, yang menurut dugaan tidak mungkin terkalahkan, ternyata menyerah juga. Pada akhir bulan tersebut, balatentara Jepang menghancurkan armada gabungan Belanda, Inggris, Australia, dan Amerika dalam pertempuran di laut Jawa. Pada tanggal 8 Maret 1942, pihak Belanda di Jawa menyerah dan Gubernur Jenderal Tjarda Van Starkenborgh Stachouwer ditawan oleh pihak Jepang. Dalam hal ini, berakhirlah kekuasaan Belanda di In- 
donesia. Orang-orang Belanda hanya meninggalkan sedikit sahabat di kalangan rakyat Indonesia. Bahkan, kalangan elite yang telah mengharapkan berlangsungnya evolusi melalui kerja sama kini benar-benar menyangsikan niat baik pihak Belanda. Dan di antara orang-orang Indonesia yang ditangkap di seluruh kepulauan ini terdapat suatu generasi pemimpin yang memandang kolonialisme Belanda sebagai beban berat yang tidak dapat ditahan lagi.

Belanda pun tumbang, dan penjajahan terhadap Indonesia dilanjutkan oleh bangsa Jepang. pada mulanya kedatangan Jepang disambut dengan suka cita. Sebab Jepang telah membantu rakyat Indonesia membebaskan dari penjajahan Belanda selama 3,5 abad. Bahkan Jepang sendiri melakukan propaganda dengan membentuk gerakan tiga A. Yakni semboyan bahwa Nippon cahaya Asia, Nippon pemimpin Asia, dan Nippon pelindung Asia. Bahkan, mereka pun berjanji akan memerdekakan bangsa Indonesia setelah usai perang pasifik melawan sekutu.

Mayoritas penduduk Indonesia adalah beragama Islam. oleh sebab itu untuk menari simpati umat Islam, Jepang menerima permintaan para ulama untuk tidak membubarkan MIAI, yakni sebuah organisasi Islam di zaman penjajah Belanda. Dengan tidak dibubarkannya MIAI, Jepang memperoleh simpati umat Islam. karena MIAI Merupakan wadah organisasi penting bagi umat Islam untuk melakukan konsolidasi dan mengatur siasat menghadapi penguasa pendudukan Jepang.

Ketika keberadaan MIAI memberikan kontribusi sangat banyak bagi umat Islam. maka setelah pihak Jepang menyadarinya, bahwa MIAI bermanfaat bagi umat Islam dan tidak memberikan keuntungan terhadap pemerintahan Jepang, maka pada akhir 1943 M Jepang membubarkan MIAI.
Setelah Jepang membubarkan MIAI, Pada tahun itu juga Jepang mengesahkan organisasi Islam baru sebagai penganti dari MIAI. Organisasi tersebut adalah MASYUMI singkatan dari Majelis Syuro Muslimin Indonesia) yang mempunyai cabangcabangnya di setiap karesidenan di Jawa. Pihak Jepang benar-benar melangkahi para politikus Islam modernis perkotaan yang sebelumnya berhasil mendominasi MIAI. Kepemimpinan Masyumi diserahkan kepada tokoh-tokoh Muhammadiyah dan NU. K. H. Hasyim Asyari, pendiri NU yang pernah dipenjarakan dengan konyol oleh pihak Jepang pada awal pendudukan mereka tapi kemudian dibebaskan pada bulan Agustus 1942, dan kemudian beliau dijadikan sebagai ketua Masyumi, namun beliau tetap tinggal di Pesantrennya di Jombang. Dan yang menjadi ketua efektif adalah putranya yakni, kiai Haji Wachid Hasyim.

Setelah berhasil menarik hati Umat Islam Indonesia dengan berbagai cara dan juga mengesahkan organisasi Masyumi. Maka pada bulan Oktober 1943, pihak Jepang membentuk organisasi pemuda Indonesia yang paling berarti, yaitu PETA (pembela tanah air). Organisasi ini merupakan suatu tentara sukarela bangsa Indonesia. Yang semenjak awal Jepang berkeinginan merekrut rakyat Indonesia menjadi pasukan atau tentara perangnya Jepang. Dari terbentuknya para pemuda Indonesia yang tergabung dalam PETA inilah gunanya untuk menyokong pasukan tempur dalam menghadapi perang melawan sekutu, saat itu Jepang mulai memobilisasi para pemuda Indonesia untuk bergabung menjadi heiho (pembantu tentara). Dari perekrutan heiho Jepang memperoleh tambahan pasukan. Secara keseluruan, anggota PETA mencapai jumlah 38.000 orang, yang terdiri dari 65 Daidan (batalyon) di Jawa dan tiga 
Daidan di Bali

Sebetulnya, peristiwa pembentukan tentara sukarela PETA tersebut adalah sebagai babak baru dari sejarah umat Islam dalam bidang kemiliteran. Yang jika sebelumnya, dalam berbagai perlawanan bersenjata terhadap pemerintah kolonial Belanda selalu dilakukan oleh pemuka agama yang dibantu oleh para petani, perajin, tukang, pedagang yang dipersenjatai yang di dalam peperangan menggunakan teknikteknik tempur tradisional, maka melalui tentara sukarela PETA tersebut, umat Islam memasuki babak baru sejarah perang modern yang mana sebagian besar umat Islam dilatih langsungoleh tentara-tentara profesional Jepang yang sejak tahun 1905 M sudah berhasil menunjukkan kehebatannya dengan menghancurkan armada Rusia dalam pertempuran di Teluk Tehusima, dan pada Maret 1942 M menghancurkan kekuatan Belanda yang didukung sekutu dalam pertempuran di Laut Jawa.

Sementara itu, Jepang secara khusus, melalui orang Jepang yang beragama Islam yakni Abdul Hamid Ono meminta kepada K. H. Wahid Hasyim agar mengerakan para santri untuk membantu Jepang dengan bergabung menjadi Heiho. Namun permintaan itu ditolak oleh K. H. Wachid Hasyim. K. H. Wachid Hasyim mengusulkan agar para santri di diberi latihan militer saja untuk pertahanan dalam negeri. Sebab mempertahankan sejengkal tanah air di dalam negeri akan lebih menguggah semangat para santri dari pada bertempur di daerah yang letaknya jauh dari tanah air. Selain itu dalam menghadapi sekutu di medan perang, dibutuhkan tentara-tentara profesional. Dalam peperangan yang besar, pemuda-pemuda yang kurang terlatih hanya akan menyulitkan tentara Jepang yang terlatih.

Permintaan itulah yang kemudian meng- ilhami K. H. Wachid Hasyim dan tokohtokoh Masyumi untuk mendidik para santri di dalam kemiliteran, yang kemudian diberi nama "Laskar Hizbullah" (tentara Allah). Para pemuda-pemuda santri di persiapkan untuk menghadapi musuh. Faktor lain yang melatar belakangi timbulnya keinginan tokoh-tokoh Islam untuk mendirikan Hizbullah ialah bahwa berperang untuk mempertahankan agama Allah hukumnya wajib.

Laskar Hizbullah berdiri secara resmi pada 14 Oktober 1944 M. dengan demikian maka umat Islam mendapatkan peluang yang besar untuk membenahi diri serta mengatur langkah dalam mencapai citacita kemerdekaannya. Keberadaan Laskar Hizbullah baik sebagai barisan untuk mengamankan agama Islam sendiri maupun sebagai alat untuk merebut kemerdekaan, keberadaan Laskar Hizbullah cukup menguatkan posisi umat Islam, meskipun tujuan pembentukannya mempunyai tendensi yang besar untuk membantu Jepang dalam menghadapi tentara sekutu.

Tiga bulan setelah Laskar Hizbullah terbentuk, tepatnya pada awal Januari 1945, Masyumi mengumumkan anggota dewan pengurus pusat Hizbullah. Sedangkan markas tertinggi Hizbullah ditetapkan di Jakarta. Kemudian untuk mengumpulkan para pemuda Islam yang akan dididik dalam kemiliteran tokoh-tokoh Islam tidak menemui kesulitan. Pendidikan kemiliteran bagi anggota Laskar Hizbullah di pusatkan di Cibarusa, Jawa Barat, diikuti sekitar 500 pemuda Islam dari Jawa dan Madura, mereka berusia antara 18-25 tahun. Diantara kota-kota yang mengirimkan utusannya adalah: Jakarta, Banten, Surabaya, Sukabumi, Priangan, Purwakerto, Bogor, Pekalongan, Kudus, Surakarta, Semarang, Pati, Jogyakarta, Madiun, Kediri, Bojonegoro, Malang, dan Besuki. Masing-masing 
mengirimkan utusan 25 orang.

Para pemuda Islam di wilayah Surabaya yang dikirim dalam latihan di Cibarusa sebanyak 14 orang pemuda dari berbagai daerah yakni, (Surabaya Mustakim Zen, Moehadjir), Moh. Rodhi As'ad, M. Ghozali (Gresik), Farchan Ahmad, Abdul Manan, Djoewaini, Masyhudi (Sidoarjo), Moelyadi, Achmad Qosim (Mojokerto), Hasyim Latief, Sa'dullah, Ma'shum, dan Moch Noer (Jombang).

Setelah kembali ke daerah masing-masing pada akhir Mei 1945, para opsir Hizbullah harus segera menyelenggarakan pelatihan militer untuk mendidik para calon anggota laskar hizbullah di daerah masing-masing. Sejak saat itulah, di seluruh wilayah karesidenan di Jawa Timur mulai dislenggarakan latihan kemiliteran di pesantren yang ditunjuk, bagi para pemuda dan santri untuk mempersiapkan diri membebaskan tanah air dari cengkeraman penjajah. Di Jombang yang sudah mengirimkan 4 orang santri yakni Hasyim Latief bersama tiga temannya yang telah lulus mengikuti latihan kemiliteran di Cibarusah, langsung mendapat perintah untuk melatih 40 orang pemuda dan santri pilihan di pesantren Seblak, Tebuireng, Jombang selama 3 bulan, dari beberapa kecamatan di daerah Jombang, serta beberapa orang santri pondok Tebuireng, Tambakberas, Denanyar, dan Rejoso. Pemuda-pemuda terlatih itulah yang menjadi komandan kompi dan komandan seksi Laskar Hizbullah Jombang dikemudian hari.

Atas perintah K. H. Hasyim Asy'ari untuk memobilisasi pemuda-pemuda seluruh kabupaten Jombang kedalam Laskar Hizbullah segera di sampaikan. Dan dalam musyawarah yang diikuti oleh beberapa tokoh terkemukah inilah terbentuk pengurus Laskar Hizbullah Jombang, yang di- antaranya: Komandan : A. Wahib Wahab. Sekertaris : Sa'dullah, dan Zaini Dahlan. Perlengkapan : Affandi, Harun, dan Machfud. Kesehatan : Hadikusumo, Farchan, Abd. Syukur. Pelatih : Hasyim Latief, Ahmad Zubair. Kerohanian: H. Fatah, Achmad, dan Ridwan. Bagian dapur : Masukri.

Laskar Hizbullah Jombang pertama kali maju ke front Surabaya sejumlah 200 orang dari kompi I yang dipimpin oleh letnan Alikar yang didampingi oleh pelatih Hasyim Latief serta beberapa orang Kiai. Mereka bersenjatakan beberapa pucuk karabiyn, beberapa peti granat, bambu runcing, pedang, kleweng keris serta senjata-senjata tradisional yang mematikan. Bambu tusuk, serta batu-batu kerikil yang diasma'i oleh para kiai-kiai sakti.

Jumlah persenjataan itu kemudian ditambah dengan beberapa pucuk karabiyn buatan Jepang serta beberapa butir granat, pinjaman dari komandan TRI Malang divisi Umardjoi yang bertahan di front Gedangan.

Dalam kongresnya di Yogyakarta yang berlangsung tanggal 7-8 November 1945, Masyumi selain memproklamirkan diri menjadi partai Masyumi juga memutuskan pembentukan markas tertinggi Laskar Hizbullah di daerah Kota Surabaya dijadikan menjadi Laskar Hizbullah divisi Sunan Ampel dengan mengangkat A. Wahib Wahab menjadi komandan Devisi.

Selanjutnya, setelah Laskar Hizbullah di seluruh karesidenan kota Surabaya disatukan menjadi divisi Sunan Ampel, yang tersusun dalam formal kepemimpinannya yakni, komanda divisi A. Wahib Wahab, kepala staf I, M. Rachmad Arief, kepala staf II, M. Samiun Somadi, sekertaris Muhansa. Dan Laskar Hizbullah divisi Sunan Ampel tersebut membawahi 4 Resimen diantaranya, resimen I berada di Mojokerto yang dipimpin oleh Mansur Solichy. Resimen II berada di 
Sidoarjo, yang di pimpin oleh Samiun Samadi. Resimen III berada di Jombang, dengan pimpinan Sa'dullah dengan kepala staff Hasyim Latief. dan yang terakhir resimen IV berada di Gresik yang dipimpin Abdul Majid Asmara.

Hasyim Latief bersama pasukan laskar hizbullah Jombang mendapat perintah untuk bersiaga di front terdepan, di jembatan putus yang terletak di sebelah utara kota Sidoarjo. Hasyim Latief berusaha berusaha mengobarkan semangat anak buahnya agar tidak gentar menghadapi musuh, meskipun persenjataannya tidak memadai. Sehari kemudian, ada seorang yang berasal dari Bawean yakni Ahmad Asnawi, menemui Hasyim Latief dengan pakaian compang camping. Dia adalah anak buah Hasyim Latief yang ditangkap dan ditawan oleh Inggris ketika dia menyelediki markas tentara Inggris di Buduran atas perintah Hasyim Latief, dan dia berhasil meloloskan diri. Asnawi melaporkan bahwa tentara Inggris telah selesai memperbaiki jembatan di Buduran. Mendengar laporan dari anak buahnya tersebut, Hasyim Latief menemui para kiai di markas kiai Desa Pagerwojo, sebelah barat kota Sidoarjo. Beliau meminta petunjuk untuk mendapatkan senjata, karena beliau dan para pasukannya hanya memiliki 7 pucuk senjata. Mendengar keluhan Hasyim Latief tersebut, seorang kiai sepuh masuk, kemudian keluar lagi dengan membawa gelas berisi air dan diberikan kepada Hasyim Latief. Hasyim Latief pun protes, karena yang diinginkan bukan senjata batin, melainkan senjata lahir berupa senapan.

Keesokan harinya, tentara Inggris dan Belanda melancarkan serangan atas Sidoarjo. Sejak subuh terdengar suara tembakan mortir amat gencar. Mendengar keadaan semacam itu, Hasyim Latief pergi ke markas kiai. Tetapi, markas sudah kosong dan seluruh isinya telah diamankan. Mereka menghindar kearah Barat, ke dapur umum yang terletak di lini kedua. Hasyim Latief segera kembali menemui pasukannya dan menyuruh mereka untuk menghindari sasaran tembak musuh. Hasyim Latief memerintahkan semua anak buah merangkak menuju rel kereta api. Ketika mereka sampai di rel kereta api, tiba-tiba muncul seorang Gurkha (pasukan bayaran Inggris berkebangsaan Nepal). Gurkha tersebut mengangkat watermantel dan menembakkannya ke arah pasukan Hasyim Latief. pasukan Hasyim Latief berlari ke kebun, Hasyim Latief sendiri bersembunyi di bawah pohon besar di balik rerimbuhan pohon bambu.

Hasyim Latief bersama anak buahnya bersembunyi hingga malam hari. Mereka baru keluar dari persembunyian ketika keadaan telah sepi. Mereka bergerak ke arah selatan melalui perkampungan dan kebunkebun sampai jalan besar. Kemudia Hasyim Latief melihat sekitar 35 tentara Inggris sedang berjaga sambil menyalahkan api. Mereka melihat Hasyim Latief bersama anak buahnya dan langsung menembakkan senjatannya dan mengenai sebuah pohon hingga tumbang. Hasyim Latief pun berlari untuk menghindari tembakkan yang bersuara kencang tersebut.

Pada 5 Mei 1947, pemerintah penyatuhkan semua kelaskaran. Dan pada 3 Juni 1947, sebagai pelaksana dari dekrit presiden No. 6 Tahun 1947 yang dikeluarkan 5 Mei, maka dekrit presiden tersebut berisi tentang pengabungan semua anggota TRI dan badan-badan kelaskaran lainnya dalam satu wadah yang bernama TNI (tentara nasional Indonesia). Karena saat itu jumlah TNI terlalu banyak dan tidak seimbang dengan jumlah persenjataan, maka pada 27 Februari 1948 pemerintah mengeluarkan ketetapan No. 9 tentang Rekon- 
truksi dan Rasionalisasi. Dari itulah semua anggota TNI jabatannya turun satu pangkat, seperti yang dialami Hasyim Latief, dari yang dulunya berpangkat kapten, menjadi komandan kompi I Yon Munasir.

Setelah Surabaya tumbang dari Belanda, beberapa hari kemudian, tepatnya 27 Juli 1947, Terjadi pertempuran di sektor Utara. Pasukan Belanda berkekuatan 5 buah tank serta dua kompi pasukan infanteri menyerang wilayah Sumobito dan kesamben. Sumadi anggota laskar hizbullah Jombang mencatat, bahwa di front ini dia kehilangan beberapa kawan seperjuangan yang gugur saat mempertahankan wilayah yang cukup strategis tersebut.

\section{Keterlibatan Munir Hasyim Latief di dalam Laskar Hizbullah}

Laskar Hizbullah berdiri secara resmi pada 14 Oktober 1944 M. dengan demikian untuk mengumpulkan para pemuda Islam yang akan dididik dalam kemiliteran tokoh-tokoh Islam tidak menemui kesulitan. Pendidikan kemiliteran bagi anggota Laskar Hizbullah di pusatkan di Cibarusa, Jawa Barat, diikuti sekitar 500 pemuda Islam dari Jawa dan Madura, mereka berusia antara 18-25 tahun. Ada 14 kota diseluruh Jawa-Madura yang mengirimkan utusan pemuda untuk dilatih kemiliteran. Diantara kota tersebut adalah Surabaya. Perwakilan Surabaya sendiri terdiri dari karesidenan-karesidenan, salah satu karesidenan Surabaya adalah Jombang. Jombang sendiri mengirimkan 4 pemuda untuk dilatih kemiliteran yang setelahnya akan melatih para laskar hizbullah di daerahnya. Empat pemuda dari Jombang tersebut adalah: Hasyim Latief, Sa' dullah, Moh. Noer, dan Ma'sum.

Dari awal, Hasyim Latief yang telah bergabung dengan hizbullah dalam latihan kemiliteran di Cibarusa tersebut adalah seorang santri yang mondok di pesantren
Tebuireng. Yang mana, sebagai seorang santri haruslah tunduk kepada perintah kiai-nya, karena semua sudah menjadi budaya bagi santri ketika berada di pondok pesantren. Ketika K. H. Wachid Hasyim anak dari K. H. Hasyim Asyari, yang menjadi ketua Masyumi pada saat itu, mengingingkan para pemuda santri untuk dilatih kemiliteran oleh Jepang, sebagai tentara cadangan. Dan akhirnya permintaan tersebut disetujui, sehingga tidak lama kemudian, para tokoh-tokoh Islam mengundang para pemuda Santri di wilayah Jawa dan Madura. Sehingga Hasyim Latief dan tiga temannya yang menjadi santri di pesantren Tebuireng mendapat perintah dari Kiai-nya untuk berangkat ke Cibarusa untuk melakukan latihan kemiliteran.

Selain perintah dari kiai di pesantrenya. Hasyim Latief yang juga masih keturunan dari darah pejuang kakeknya, beliau sangat semangat. Karena mengingat ayahnya pada saat kecilnya pernah dipenjarah oleh penjajah Belanda. Dari situlah penulis bisa menganalisis bahwa, keterlibatan perjuangan Hasyim Latief dalam perang mempertahankan kemerdekaan tersebut dipengaruhi dari beberapa faktor, diantaranya adalah, suruhan dari kiai, karena sebagai santri beliau harus ta'dhim terhadap kiai yang menjadi pemimpin pesantren. selian itu, perjuangan Hasyim Latief juga tumbuh dari jiwanya sendiri karena ayahnya pernah dipenjarah oleh penjajah Belanda ketika itu.

\section{Kesimpulan}

Nama aslinya Hasyim Latief, beliau adalah seorang tokoh lokal yang ikut berjuang dalam perang mempertahankan kemerdekaan. Sejak kecil beliau tidak pernah belajar di bangku sekolah formal. Karena dari itulah ayahnya memondokkan beliau ke pesantren Tebuireng yang diasuh oleh K. H. Hasyim Asy'ari. Dari pesantren Te- 
buireng inilah beliau bisa mengikuti perang mempertahankan kemerdekaan dengan diadakannya pelatihan kemiliteran oleh pihak Jepang yakni Laskar Hizbullah.

Di laskar hizbullah, beliau menjadi pelatih laskar hizbullah Jombang setelah kepulangannya dari latihan yang diadakan Jepang di Cibarusa Bogor. Di samping menjadi pelatih, ketika dalam penyerbuan ke Sidoarjo dan Surabaya, beliau bertindak sebagai komandan, karena pada saat itu anggotanya bubar sendiri-sendiri, dan mau tidak mau beliaulah yang mengordinir anggotanya kembali dengan merangkap sebagai pelatih sekaligus komandan tempur.

Dalam keikut sertaannya beliau di laskar hizbullah tersebut. penulis beranggapan bahwa, beliau adalah seorang santri, yang mana dalam tradisi pesantren, jika ada seorang santri disuruh oleh kiainya, maka seorang santri tersebut harus mematuhinya. Dari situlah Hasyim Latief yang pada saat itu sebagai santri Tebuireng harus patu pada kiai yang menyuruh beliau berangkat untuk mengikuti latihan di Cibarusa Bogor. Selain itu, beliau juga ada kemauan sendiri karena beliau masih ada keturunan darah pejuang dari kakeknya.

\section{Referensi}

M. C. Ricklefs. Sejarah Indonesia Modern 12002008. Jakarta: PT. Serambi Ilmu Semesta, 2008.

Sartono Kartodirdjo. Pendekatan ilmu sosial dalam metodologi sejarah. Jakarta: Gramedia Pustaka Utama, 1992.

Kuntowijoyo. Pengantar ilmu sejarah. Yogyakarta: Yayasan Benteng Budaya, 1995.

Kuntowijoyo. Metodologi sejarah. Yogyakarta: Tiara Wacana, 2003.

Hasyim Latief. Laskar Hisbullah berjuang menegakkan Negara RI. Surabaya: PT. Jawa Pos, 1995.

A. Fathoni Rodli Dkk. KH. M. Hasyim Latief Ulama Pejuang Dan Pendidik. Sidoarjo: Yayasan Pendidikan Dan Sosial Ma'arif YPM, 2005.

Soeleiman Fadeli dan Mohammad Subhan. Antologi NU buku II: sejarah istilah amaliah uswah. Surabaya: Khalista, 2010.

Moch. Faisol. Jejak Laskar Hizbullah Jombang. Tanpa Kota: Pustaka Tebuireng, 2018.

Suratmin. Perjuangan Laskar Hizbullah dalam pertempuran Surabaya 10 November 1945. Yogyakarta: Matapadi Presindo, 2017.

Isno El-Kayyis. Perjuangan Laskar Hizbullah di Jawa Timur. Jombang: Pustaka Tebuireng, 2015. 